\title{
The MILP Model for Locating the Temporary Disaster Emergency Operation Centers in Manado Indonesia
}

\author{
Andre Ch. Lasut, Prudensy F. Opit *, Ronaldo Rottie \\ Industrial Engineering Department, Universitas Katolik De La Salle Manado, Indonesia \\ Jl. Kairagi I Kombos Manado, Kairagi Satu, Manado, Indonesia \\ * Corresponding author: popit@unikadelasalle.ac.id
}

\section{ARTICLE INFO}

Article history

Received November 4, 2019

Revised February 20, 2020

Accepted February 26, 2020

Available Online February 28, 2020

Keywords

Disaster management

Disaster relief

Flood emergency response

MILP model

Temporary facility location

\begin{abstract}
The research proposes the Mixed Integer Linear Programming Model (MILP). This model integrates the location decisions and the number of temporary Emergency Operations Center (EOC) to be constructed. This model also focuses on events related to natural disasters, particularly floods. The researchers applied this model according to the flood scenario in five flood-prone districts in Manado, Indonesia. This research focused on maximizing the number of temporary constructed EOCs to provide the relief demands of disaster areas by considering multiple periods. The available budgets were considered as the limited constraints in this model. Therefore, the results showed that the percentage of relief demand satisfaction ranges from $28 \%$ to $100 \%$; meanwhile, the number of the to-be-constructed temporary EOCs ranges from 0-3 for each scenario.
\end{abstract}

This is an open-access article under the CC-BY-SA license.

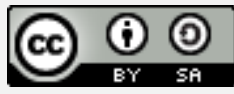

\section{Introduction}

Manado is one of the cities in Indonesia, which has a high risk of flooding disasters [1] [2]. Flood incidents in Manado have significantly increased in the last ten years [3]. In January 2014, Manado and its surrounding areas were hit by flash floods. This disaster made a considerable impact causing IDR 1.87 trillion (133,072,000 USD) worth of economic damage. After the disaster, a total of 10,844 houses were destroyed, 20,244 families, and 85,831 people were affected and evacuated [4]. According to the North Sulawesi Disaster Management Board (BPBD SULUT), many victims could not be assisted immediately due to the limited number and capacity of the Emergency Operations Center (EOC). Therefore, many of the people affected by the disaster suffered due to the lack of service. Based on studies by Sahetapy et al. [5], Sudamara [6], and Hasan et al. [7], the riverside area is the area with a high potential to be affected by floods. Hence, the evacuation site must be far from the watershed. A disaster such as floods, earthquakes, and tsunamis are substantially problematic to predict. Therefore, governments need to organize a better plan to deal with the upcoming disaster.

The Disaster Operations Management (DOM) issues have been widely discussed in recent years. Disaster operations are a set of activities carried out before, during, and after a disaster comes with the primary objective of preventing the loss of human life [8]. 
There are four stages in DOM: mitigation, preparedness, response, and recovery; the response stage ranks as the most operational stage discussed in studies related to DOM [9], [10]. DOM facility location modeling is a fundamental approach to plan pre-and postdisaster operations [11]. Sebatli et al. [12] offer a simulation-based approach to determine the number of requests, develop a plan to allocate temporary disaster response facilities, and distribute relief supplies to the affected area. Another research has discussed the optimization model for temporary facility location and resource distribution by considering the possibilities of transfer of excess resources [13]. Optimization modeling for emergency locations has been proposed by Wuyang [14] and Cauhnye [15].

Furthermore, a survey on the facility location problems related to emergency humanitarian logistics based on modeling and problem types has been conducted [11]. There is also a research model of disaster emergency location optimization by considering the Istanbul government's potential and impact [16]. Akgun et al. [17] determine the optimal location that considers the possible risks and consequences of threats to the site with the least risk. Post-disaster management is vital for community recovery, one of which is being studied by Boonmee et al. [18]. Baharmand [19] defines that the main challenge of limited time, resources, and costs by reducing logistical costs is quite substantial. The most important thing is to save the lives of the victims by creating an emergency post-hospital and minimizing the patient time to the site [20], [21]. Kawasaki, et al. [22] investigate disaster responses of the Government of Myanmar. Milburn et al. [23] focused on the Disaster Response Planning Model that locates the relief distribution points using real-time information on the actual damage to transport infrastructures. A multi-criteria optimization model integrated with GIS for locating emergency facilities with a case study of worst-case flood scenarios (based on water level) has also been discussed [24]. Espindola [25] and Abror [26] determine the potential locations for optimal disaster evacuation using GIS tools. In some instances, facility disruptions can also focus on relief supplies pre-positioning issues in DOM [27]. Klibi [28] discusses the location of emergency supply with three phases to obtain an optimal solution. Renkli [29] develops a model of the warehouses' placement using the Mixed Integer Programing approach so that the locations are not affected by the disaster. Rawis et. al [30] determine the optimal shelter pre-placement by making pre-planning with meeting short demands. At the same time, Abounacer [31] examines the disaster emergency transportation response to minimize the total transportation time, number of agents, and non-covered demand.

Based on the previous studies, many researchers have developed several different models to locate the facilities in a disaster incident. However, there have not been any studies discussing the possibility (scenario) of disaster occurrence in multiple areas. In the real world, disasters can occur in various locations at the same time. By adding the scenario of disaster occurrence into the model, the researchers can quickly determine the best location and number of facilities to be opened. The researchers found an interesting article by Milburn et al. [23]. Then, the researchers modified the mathematical model of disaster relief shelter location and supply routing in the article to make it compatible to be applied in Manado. In this case, the researchers added a new set of scenarios of disaster (floods) occurrence that was not taken into account in the previous work. Therefore, this research proposes a new MILP model that aims to determine the maximum number of temporary Emergency Operations Center (EOC) to be opened (constructed) to provide the relief demand for disaster areas by considering some scenarios. This research is also intended to support the local government (BPBD SULUT) to make a quick decision and improve their performance related to the disaster 
emergency response. Expectantly, it can reduce the number of affected victims. The outline of this article is as follows; Section 1 discusses the introduction of the research that describes the literature review, research novelty, and research objective. Section 2 describes the research methodology divided into problem definition and assumptions, research framework, data construction, and mathematical model formulation. Section 3 describes results and discussion (the computational result and analysis). Section 4 presents the research conclusion and possible future work.

\section{Methods}

\subsection{Research Framework}

The framework of this research is shown in Fig. 1. The researchers conducted a preliminary observation of the disaster management system implemented by BPBD Sulut. The initial observations were carried out to analyze the crucial issues. Furthermore, the researchers identified the problem. Based on this problem, the researchers conducted a literature review and determined the objective of this research.

Further, the researchers developed the new MILP model approach. Variables and parameters were identified to construct the objective function and constraints. Subsequently, the new mathematical model was formulated. The data were collected through documentation analysis, observation, and interviews with the Logistics Manager, their subordinates, and other employees in BPBD Sulut. Once the data were complete, the researchers ran the model using LINGO Solvers. A model modification was needed when the results were not yet valid. Moreover, the researchers analyzed the results and compared each scenario. Finally, the researchers concluded and provided a quick overview of future research developments.

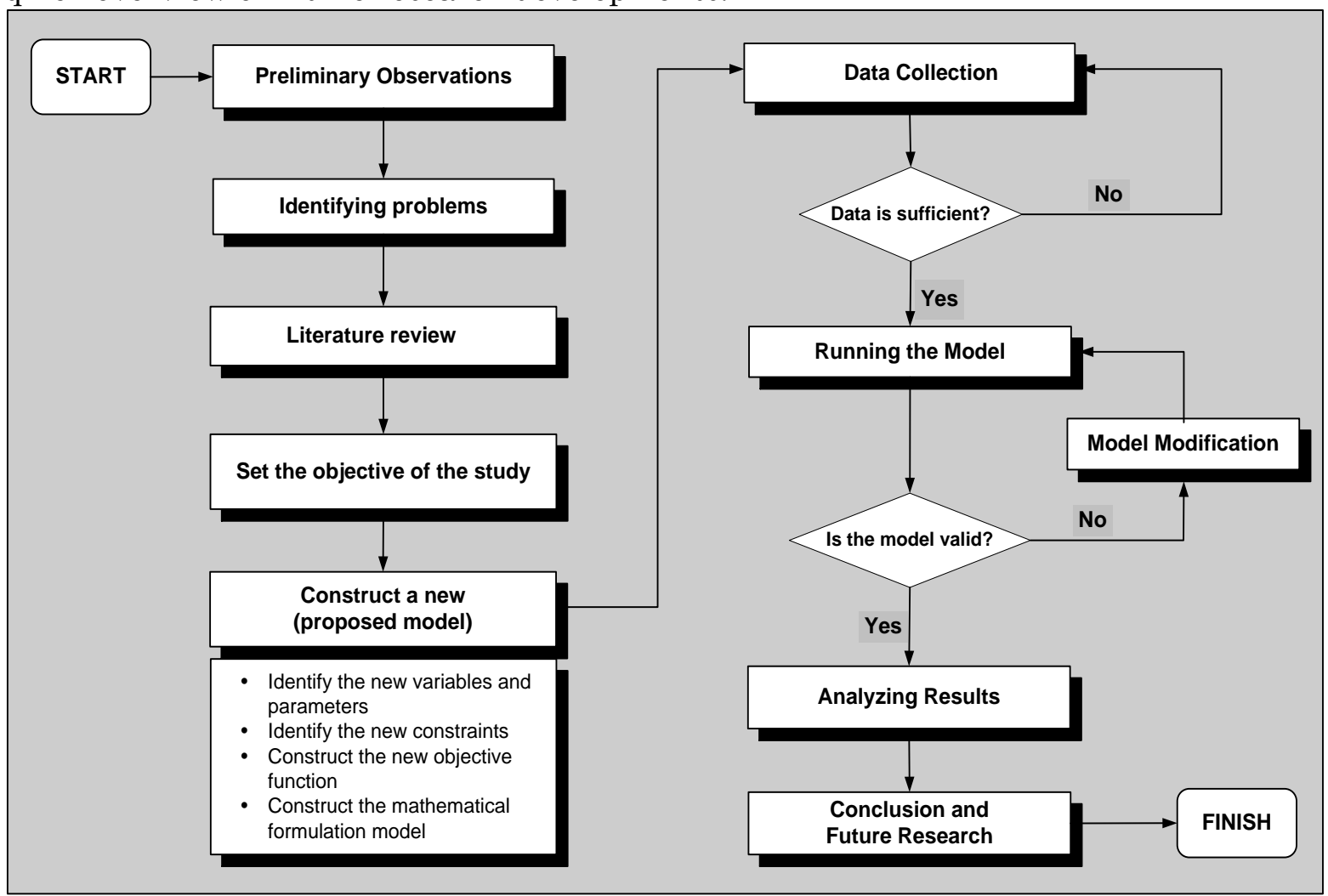

Fig. 1. Flow chart of research methodology 


\subsection{Problem Definition and Assumptions}

Based on the mixed-integer programming model constructed by Milburn et al. [23], the researchers developed the new MILP model following these assumptions: 1) A set of demand points was known, 2) A set of potential EOC locations was known, 3) Each EOC had a capacity limit, and 4) Service period began at the time when a disaster occurred, and it was implemented at discrete time intervals. Due to the limited research time, the researchers also made some crucial assumptions as follows: 1) This research focused only on five flood-prone districts in Manado, namely disaster areas 1, 2, 3, 4, and 5 (based on the information gathered from BPBD Sulut). 2) This research focused on the first 24 hours of emergency response after a disaster occurred. 3) This research was conducted using historical data on floods in North Sulawesi from January 2014 to January 2019.

\subsection{Mathematical Model Formulation}

The researchers proposed A new MILP model. The indexes such as I, J, T, and S. $\mathrm{I}=[1 \ldots, \mathrm{i})$ are the set of disaster areas, and $\mathrm{J}=\{1,2,3, \ldots, \mathrm{j}]$ represents the set of EOC candidates. Meanwhile, $\mathrm{T}=\{1,2, \ldots, t\}$ shows the set of periods, and $\mathrm{S}=\{1,2,3, \ldots, s)$ describes the set of flood occurrence scenario. Parameters and decision variables used in this model as follow.

\section{Parameters}

Dit : Expected demand in disaster area $i$ in period $t$ (unit)

Hijt : Distance from disaster area $i$ to EOC candidate $j(\mathrm{~km})$

$\mathrm{Cf} \quad$ : EOC construction cost (IDR)

Co : EOC operating cost (IDR)

B : Total budget for constructing and operating EOC (IDR)

Q : EOC capacity (unit)

$\mathrm{D} \quad$ : Maximum distance from disaster area $i$ to EOC candidate $j(\mathrm{~km})$

M : Large positive number

\section{Decision variables}

Xijts $\quad: 1$, if disaster area $i$ is served by EOC $j$ in period $t$ for scenario $s$, otherwise 0 Aijts $\quad$ Demand percentage in disaster area $i$ that can be satisfied by EOC $j$ in
period $t$ for scenario $s$ Zjts : 1 , if EOC candidate $j$ in period $t$ for scenario $s$ is opened (constructed),

Yjts $\quad: 1$, if EOC candidate $j$ operates in period $t$ for scenario $s$, otherwise 0

Objective functions:

Maximize $Z=\sum_{i \in I} \sum_{j \in J} \sum_{t \in T} \sum_{s \in S}\left(D_{i t} A_{i j t s}-M H_{i j t} X_{i j t s}\right)$

Subject to:

$\begin{array}{ll}\sum_{j \in J} X_{i j t s} \leq 1 & \forall i \in I, \forall j \in J, \forall t \in T \forall s \in S \\ Y_{j t s} \geq \sum_{t \in T} Z_{j t s} & \forall j \in J, \forall t \in T, \forall s \in S \\ Y_{j t s} \leq \sum_{t \in T} Z_{j t s} & \forall j \in J, \forall t \in T, \forall s \in S \\ \sum_{t \in T} Z_{j t s} \leq 1 & \forall j \in J, \forall s \in S \\ A_{i j t s} \leq X_{i j t s} & \forall i \in I, \forall j \in J, \forall t \in T, \forall s \in S \\ \sum_{j \in J} \sum_{t \in T}\left(Z_{j t s} C_{f}+Y_{j t s} C_{o}\right) \leq B & \forall s \in S \\ \sum_{i \in I} A_{i j t s} D_{i t} \leq Q Y_{j t s} & \forall j \in J, \forall t \in T, \forall s \in S\end{array}$




$$
\begin{array}{ll}
h_{i j t} X_{i j t s} \leq D & \forall i \in I, \forall j \in J, \forall t \in T, \forall s \in S \\
X_{i j t s} \in\{0.1\} & \forall i \in I, \forall j \in J, \forall t \in T, \forall s \in S \\
Z_{j t s} \in\{0.1\} & \forall j \in J, \forall t \in T, \forall s \in S \\
Y_{j t s} \in\{0.1\} & \forall j \in J, \forall t \in T, \forall s \in S \\
A_{i j t s} \geq 0 & \forall i \in I, \forall j \in J, \forall t \in T, \forall s \in S
\end{array}
$$

Equation (1) is the objective function to maximize the number of EOCs to provide the demand in each disaster area during a specific period. Constraint (2) ensures that one EOC serves each disaster area for each period. Constraint (3) guarantees that the opened EOC continues to operate until a certain period. Constraint (4) ensures that the unopened EOC cannot be operated. Constraint (5) ensures that each EOC can only be opened once. Constraint (6) guarantees that the demand cannot be satisfied by a specific EOC when the EOC does not operate in a certain period for each scenario. Constraint (7) ensures that the budgets required for opening and operating the EOC do not exceed the total provided budget. Constraint (8) requires that the capacity of the to-be-opened EOC does not exceed the demand. Constraint (9) ensures that the distance between disaster areas and the to-be-opened EOC does not exceed the maximum allowed distance. Constraint (10), (11), and (12) define the binary variables. Constraint (13) describes the non-negativity constraint.

\subsection{Data Collection}

\subsubsection{Disaster Area and EOC Candidates}

The disaster areas were the five flood-prone districts in Manado. Eighteen EOC candidates were determined based on the conditions given by BPBD Sulut, such as 1) The buildings that can be used for EOC is the church, mosque, or school with a capacity of five-thousand people, and 2) The candidate location must be easily accessible using transportation (near the highway) and free from floods. In this research, the selected EOC candidates were schools and places of worship located in flood-free locations or far from the river, and they are easily accessible by land (ground) transportations. In this case, EOC candidates 1, 2, 3, and 4 were located in disaster area 1; EOC candidates 7, 8, $15,16,17$, and 18 were located in disaster area 2 ; no EOC candidate was located in disaster area 3 (zero EOC candidate); EOC candidates 5, 6, and 9 were located in disaster area 4; and EOC candidates 10,11, 12, 13, and 14 were located in disaster area 5 .

\subsubsection{Service Period, Number of Relief Demand, and Distance From The Disaster Area to EOC Candidates}

The researchers described that the service period is limited to the first twentyfour hours. During that period, the government was required to make a quick decision in dealing with the floods. The first twenty-four hours were divided into two periods (every twelve hours) for the construction and operation of the new EOC. Meanwhile, the number of demands was assumed according to the historical data of flood victims gathered from BPBD Sulut. Based on this information, the average percentage of people affected by floods could reach up to $30 \%$ of the population in each district. Therefore, the researchers determined that the number of demands in the first period was $10 \%$ of the population of each district and $20 \%$ of the total population of each district in the second period. The demand inventory was assumed to be always available in each EOC. The distance from the disaster area to the EOC candidate was obtained using Google Maps. The distance was measured from the flooded location in each district to the site of the EOC candidates. 


\subsubsection{Budget}

The budgets used in this study were based on that of BPBD SULUT. The EOC construction cost as much as IDR 10,000,000 per EOC is used to construct public kitchens and the provision of infrastructure needed for disaster management. The operating cost, such as food cost for the workers and transportation cost, is IDR $7,500,000$. The total costs provided by the government are IDR 100,000,000 per year.

\subsubsection{Scenarios of Floods Occurrence}

In this study, floods can occur at the same time in several different disaster areas. Finally, the researchers generated 32 scenarios, as seen in Table 1 . If the value is 1 , major floods occur in that specific disaster area. On the contrary, if the value is 0 , no significant floods occur in that particular disaster area. The researchers operated this model with thirty-two scenarios, eighteen EOCs, five disaster areas, and two periods of time. Based on the mathematical model presented in section 2.3, the researchers encoded the formulation using LINGO version 11.0 on an intel Celeron with 2 GB RAM. The computation time was less than one minute.

Table 1. Scenario of Flood Occurrence

\begin{tabular}{|c|c|c|c|c|c|}
\hline \multirow[b]{2}{*}{ Scenario } & \multicolumn{5}{|c|}{ Disaster Area } \\
\hline & (1) & $(2)$ & (3) & (4) & (5) \\
\hline 1 & 0 & 0 & 0 & 0 & 0 \\
\hline 2 & 0 & 0 & 0 & 0 & 1 \\
\hline 3 & 0 & 0 & 0 & 1 & 0 \\
\hline 4 & 0 & 0 & 1 & 0 & 0 \\
\hline 5 & 0 & 1 & 0 & 0 & 0 \\
\hline 6 & 1 & 0 & 0 & 0 & 0 \\
\hline 7 & 0 & 0 & 0 & 1 & 1 \\
\hline 8 & 0 & 0 & 1 & 0 & 1 \\
\hline 9 & 0 & 1 & 0 & 0 & 1 \\
\hline 10 & 1 & 0 & 0 & 0 & 1 \\
\hline 11 & 0 & 0 & 1 & 1 & 0 \\
\hline 12 & 0 & 1 & 0 & 1 & 0 \\
\hline 13 & 1 & 0 & 0 & 1 & 0 \\
\hline 14 & 0 & 1 & 1 & 0 & 0 \\
\hline 15 & 1 & 0 & 1 & 0 & 0 \\
\hline 16 & 1 & 1 & 0 & 0 & 0 \\
\hline 17 & 0 & 0 & 1 & 1 & 1 \\
\hline 18 & 0 & 1 & 0 & 1 & 1 \\
\hline 19 & 1 & 0 & 0 & 1 & 1 \\
\hline 20 & 0 & 1 & 1 & 0 & 1 \\
\hline 21 & 1 & 0 & 1 & 0 & 1 \\
\hline 22 & 1 & 1 & 0 & 0 & 1 \\
\hline 23 & 0 & 1 & 1 & 1 & 0 \\
\hline 24 & 1 & 0 & 1 & 1 & 0 \\
\hline 25 & 1 & 1 & 0 & 1 & 0 \\
\hline 26 & 1 & 1 & 1 & 0 & 0 \\
\hline 27 & 0 & 1 & 1 & 1 & 1 \\
\hline 28 & 1 & 0 & 1 & 1 & 1 \\
\hline 29 & 1 & 1 & 0 & 1 & 1 \\
\hline 30 & 1 & 1 & 1 & 0 & 1 \\
\hline 31 & 1 & 1 & 1 & 1 & 0 \\
\hline 32 & 1 & 1 & 1 & 1 & 1 \\
\hline
\end{tabular}




\section{Results and Discussion}

\subsection{The Potential EOCs and The Number of Satisfied Relief Demands}

Table 2 and Table 3 show the results of the potential of the to-be-opened EOCs and the percentage of the number of demands satisfied in periods 1 and 2 for each flood occurrence scenario. No EOC was opened in scenario 1, either in period 1 or 2 , as no disaster occurred. In scenario 2 (referring to Table 1), the floods occurred only in the disaster area 5 . In this case, only one potential EOC was to be opened in period 1, which was EOC 13; it was also located in disaster area 5. Meanwhile, in period 2, there were two potential EOCs to be opened, which are EOC 11 and EOC 14. Both potential EOCs were located in the disaster area 5 . Another result, for example, in scenario 7 , the floods occurred in two disaster areas (4 and 5) at the same time. In this case, three potential EOCs were to be opened in period 1, which were EOC 7 (disaster area 2), EOC 9 (disaster area 4), and EOC 11 (disaster area 5). Meanwhile, in period 2, two potential EOCs were opened, namely EOC 6 (disaster area 4) and EOC 13 (disaster area 5).

Table 2. Potential EOCs to be opened in period 1

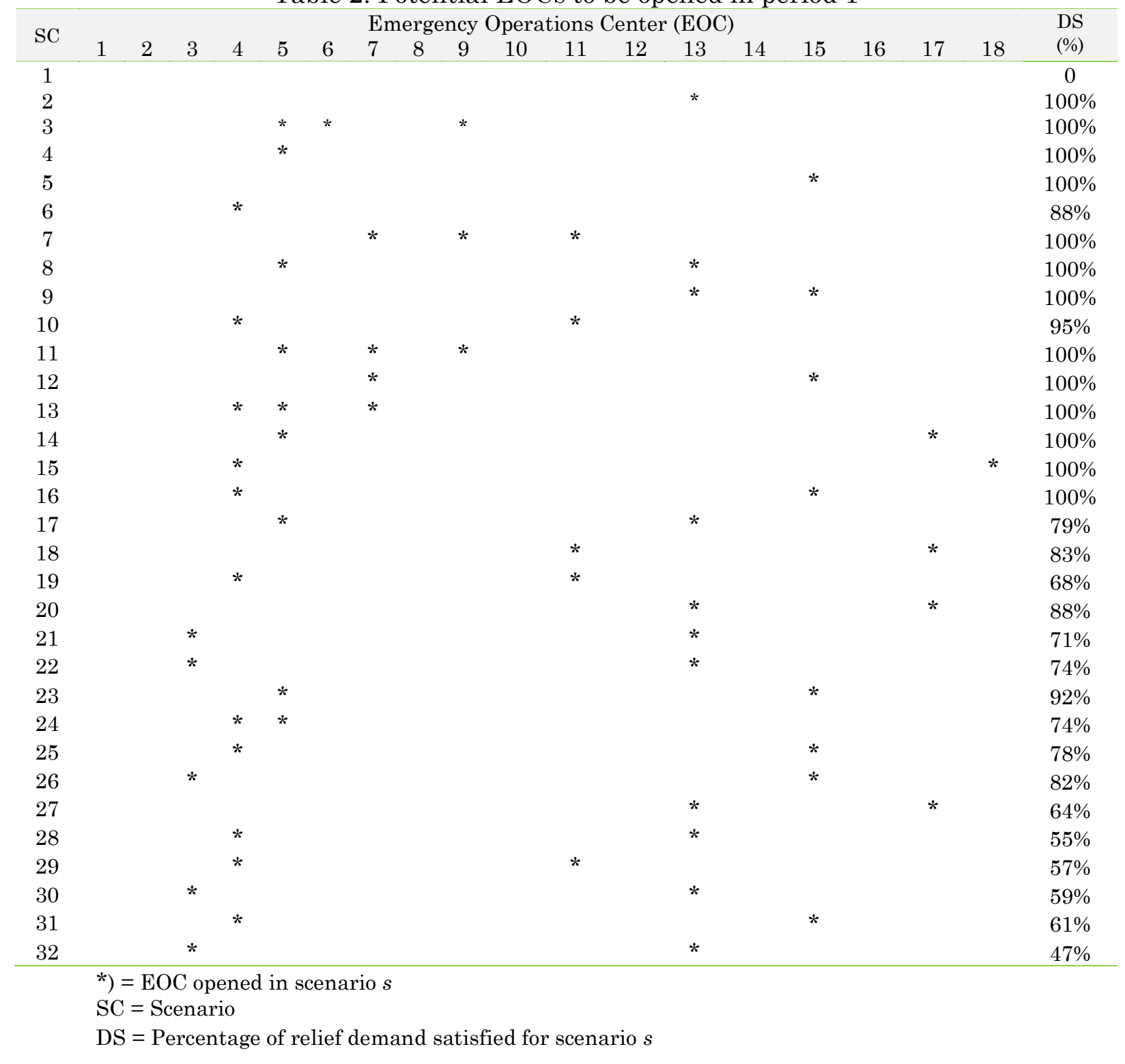


Table 3. Potential EOCs to be opened in period 2

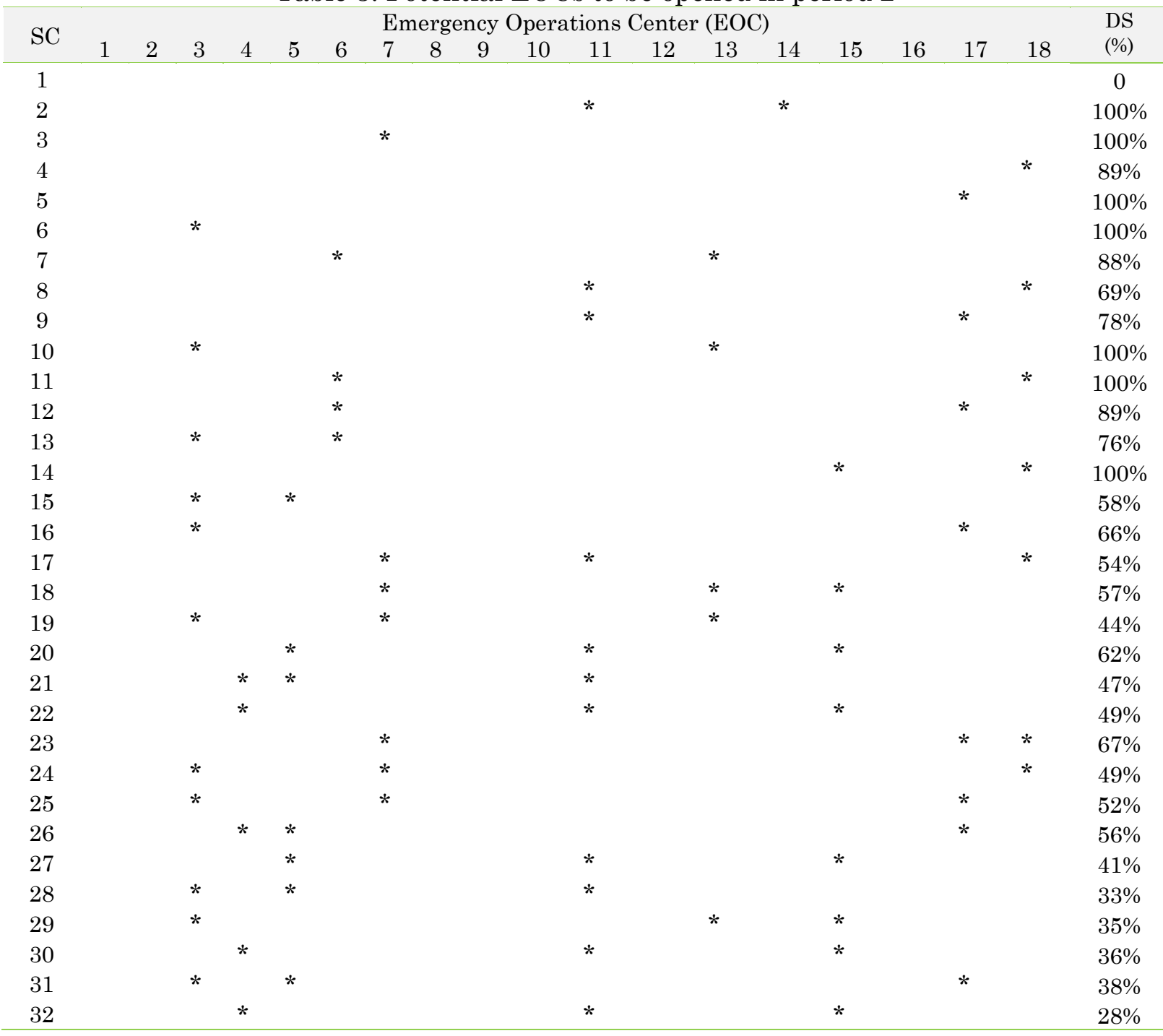

*) $=$ EOC opened in scenario $s$

$\mathrm{SC}=$ Scenario

DS $=$ Percentage of relief demand satisfied for scenario $s$

The last scenarios show that the floods occurred in all five disaster areas at the same time. There were two potential EOCs to be opened in period 1, namely EOC 3 (disaster area 1) and EOC 13 (disaster area 5). Meanwhile, in period 2, there were three potential EOCs to be opened, which were EOC 4 (disaster area 1), EOC 11 (disaster area 5), and EOC 15 (disaster area 2). However, there was a consistent tendency for not opening EOC 1 and EOC 2, located in disaster area 1 for all scenarios. Instead, the proposed model chose to open EOC 3 and EOC 4, which were situated in disaster area 1.

Scenario 1 indicated zero floodings in all disaster areas (see Table 1). In scenario 2 , where the floods occurred only in disaster area 5 , the percentage of demand satisfied in periods 1 and 2 was $100 \%$. It shows that the demand in disaster area 5 was completely satisfied for both periods. Meanwhile, in scenario 32, where the floods occurred in all disaster areas, the number of demands satisfied decreased as much as $47 \%$ in period 1 
and $28 \%$ in period 2 . It illustrates a decline in service as the number of disaster areas and the periods got bigger.

Based on these results, the researchers acknowledge that the restrictions on budgets, distance, and the number of periods are profoundly affected by the number of satisfied relief demands. Hence, the researchers consider budget availability as one of the most restricted constraints in this model. The larger the budgets available are, the higher the percentage of the number of satisfied relief demands will be.

\subsection{Comparison of The Satisfied Relief Demands}

Table 4 compares the minimum and maximum percentage of the satisfied demand among the scenarios with different flood events. For scenarios 2-6, the floods occurred only in one disaster area. The percentage of the satisfied demand could reach up to a maximum of $100 \%$ and a minimum of $88 \%$. It was still relatively high. For scenarios 7-16, the floods occurred in two disaster areas at the same time. The maximum percentage could also reach $100 \%$, although the minimum rate of the satisfied demand decreased to $58 \%$. For scenarios 17-26, the floods occurred in three disaster areas at the same time. The maximum rate dropped to $92 \%$; meanwhile, the minimum percentage of the satisfied demand decreased to $44 \%$.

Table 4. Comparison of the percentage of the satisfying demand

\begin{tabular}{llcc}
$\begin{array}{c}\text { Number of the } \\
\text { disaster area }\end{array}$ & Scenario applied & $\begin{array}{c}\text { Minimum percentage } \\
\text { of demand satisfied }\end{array}$ & $\begin{array}{c}\text { The maximum } \\
\text { percentage of demand } \\
\text { satisfied }\end{array}$ \\
\hline 1 district & Scenario $2-6$ & $88 \%$ & $100 \%$ \\
2 districts & Scenario $7-16$ & $58 \%$ & $100 \%$ \\
3 districts & Scenario $17-26$ & $44 \%$ & $92 \%$ \\
4 districts & Scenario $27-31$ & $33 \%$ & $82 \%$ \\
5 districts & Scenario 32 & $28 \%$ & $47 \%$ \\
\hline
\end{tabular}

For scenarios 27-31, the floods occurred in four disaster areas at the same time. The maximum percentage of the satisfied demand dropped to only $82 \%$; meanwhile, the minimum rate of the satisfied demand significantly decreased to $33 \%$. For scenario 32 , where the floods occurred in all five disaster areas simultaneously, the maximum percentage of the satisfied demand progressively decreased to only $47 \%$; meanwhile, the minimum percentage of the satisfied demand was deficient at $28 \%$. Compared to the previous research conducted by Milburn et al. [23], without adding a set of scenarios of flood occurrence, their result showed that the percentage of the demand satisfied in each period varied between $0 \%$ and $92 \%$. The number of the opened facilities also ranges from 0 (early period) to 32 (final period). It suggests a pattern of not opening any facility in the early periods of their model. It may be due to the lack of knowledge about the demand requirements during the early periods of the post-disaster relief.

Finally, as shown in Table 4, the percentage of the satisfying relief demand shrank as the floods occurred in several disaster areas at the same time. It was due to the limited budgets provided by the government. Thus, It is strongly recommended that the government (BPBD Sulut) increase the budgets for the disaster emergency response to provide better services and minimize human suffering and loss. 


\section{Conclusion}

This research proposes a new MILP model. This model aims at determining the maximum number of temporary to-be-opened EOCs to satisfy the relief demand for disaster areas. This model is built by adding a new set of scenarios of flood occurrence. Using five flood-prone districts in Manado as a case study, the researchers generate a total of thirty-two flood occurrence scenarios. The results show that the number of potential EOCs to be opened for each scenario varies, both in the first and second periods. Based on these results, the locations of the potential EOCs to be opened are still within the maximum allowed distance. The number of relief demands satisfied by potential EOCs in periods 1 and 2 for scenarios 2-32 also varies. Since scenario one does not have any flood events, the number of satisfied relief demands by the potential EOCs in periods 1 and 2 equal to zero.

The researchers reveal that the governments' availability of budgets can be considered one of the most restricted constraints in this model. Therefore, increasing disaster management budgets can be considered as a solution to improve services in the future. For further research, a stock pre-positioning model can be implemented and taken into account in this model.

\section{References}

[1] R. Riyandari, "'Water Front City" Mitigasi Bencana Banjir Di Kelurahan Dendengan Luar, Kota Manado," Jurnal Sains dan Teknologi Mitigasi Bencana, vol. 13, pp. 57-64, 2018. https://doi.org/10.29122/jstmb.v13i1.3361.

[2] B. Laurensz, F. Lawalata, and S. Y. J. Prasetyo, "Potensi Resiko Banjir dengan Menggunakan Citra Satelit (Studi Kasus: Kota Manado, Provinsi Sulawesi Utara)," Indonesian Journal of Computing and Modeling, vol. 2, pp. 17-24, 2019. https://ejournal.uksw.edu/icm/article/view/2536.

[3] A. Rinaldi, D. Pohan, and I. Moe, Evaluasi Permasalahan Banjir Kota Manado Dengan Pemodelan Dua 2018. https://doi.org/10.13140/RG.2.2.28625.79205.

[4] N. SP. (January 22, 2014, march 01). Update Banjir Bandang Manado.

[5] G. B. Sahetapy and H. Poli, "Analisis Jalur Evakuasi Bencana Banjir Di Kota Manado," SPASIAL, $\quad$ vol. $\quad 3, \quad$ pp. $\quad 70-79, \quad 2016$. https://ejournal.unsrat.ac.id/index.php/spasial/article/view/12536.

[6] Y. Sudamara, B. F. Sompie, and R. J. Mandagi, "Optimasi penanggulangan bencana banjir Di kota manado dengan metode AHP (analytical hierarchy process)," Jurnal Ilmiah Media Engineering, vol. 2, 2012. https://ejournal.unsrat.ac.id/index.php/jime/article/download/4247/3776.

[7] P. F. Opit, "A MILP Model for Locating the Temporary Disaster Emergency Operations Centers in Manado Indonesia," 2020, vol. 21, 2020. https://ejournal.umm.ac.id/index.php/industri/article/view/10165.

[8] N. Altay and W. G. Green, "OR/MS research in disaster operations management," European Journal of Operational Research, vol. 175, pp. 475-493, 2006. https://doi.org/10.1016/j.ejor.2005.05.016.

[9] G. Galindo and R. Batta, "Review of recent developments in OR/MS research in disaster operations management," European Journal of Operational Research, vol. 230, pp. 201-211, 2013. https://doi.org/10.1016/j.ejor.2013.01.039.

[10] N. Tungtisanont, A. V. Roth, Y. B. Ferrand, and T. A. Mroz, "Disaster Operations Management: an Empirical Study from Thailand," 2015. 
[11] C. Boonmee, M. Arimura, and T. Asada, "Facility location optimization model for emergency humanitarian logistics," International Journal of Disaster Risk Reduction, vol. 24, pp. 485-498, 2017. https://doi.org/10.1016/j.ijdrr.2017.01.017.

[12] A. Sebatli, F. Cavdur, and M. Kose-Kucuk, "Determination of relief supplies demands and allocation of temporary disaster response facilities," Transportation $\begin{array}{lllll}\text { Research Procedia, } & \text { vol. } 22, \quad \text { pp. }\end{array}$ https://doi.org/10.1016/j.trpro.2017.03.031.

[13] D. W. Khayal, "Dynamic Locations Of Temporary Distribution Facilities For Emergency Response Planning," Qatar University, 2015.

[14] W. Yu, "Reachability guarantee based model for pre-positioning of emergency facilities under uncertain disaster damages," International Journal of Disaster Risk Reduction, vol. 42, p. 101335, 2020. https://doi.org/10.1016/j.ijdrr.2019.101335.

[15] A. M. Caunhye, X. Nie, and S. Pokharel, "Optimization models in emergency logistics: A literature review," Socio-Economic Planning Sciences, vol. 46, pp. 4-13, 2012. https://doi.org/10.1016/j.seps.2011.04.004.

[16] N. Görmez, M. Köksalan, and F. S. Salman, "Locating disaster response facilities in Istanbul," Journal of the Operational Research Society, vol. 62, pp. 1239-1252, 2011. https://doi.org/10.1057/jors.2010.67.

[17] İ. Akgün, F. Gümüşbuğa, and B. Tansel, "Risk based facility location by using fault tree analysis in disaster management," Omega, vol. 52, pp. 168-179, 2015. https://doi.org/10.1016/j.omega.2014.04.003.

[18] C. Boonmee, M. Arimura, and T. Asada, "Location and allocation optimization for integrated decisions on post-disaster waste supply chain management: On-site and off-site separation for recyclable materials," International Journal of Disaster Risk Reduction, vol. 31, pp. 902-917, 2018. https://doi.org/10.1016/j.ijdrr.2018.07.003.

[19] H. Baharmand, T. Comes, and M. Lauras, "Bi-objective multi-layer locationallocation model for the immediate aftermath of sudden-onset disasters," Transportation Research Part E: Logistics and Transportation Review, vol. 127, pp. 86-110, 2019. https://doi.org/10.1016/j.tre.2019.05.002.

[20] P. Memari, R. Tavakkoli-Moghaddam, M. Partovi, and A. Zabihian, "Fuzzy Dynamic Location-Allocation Problem with Temporary Multi-Medical Centers in Disaster Management," IFAC-PapersOnLine, vol. 51, pp. 1554-1560, 2018. https://doi.org/10.1016/j.ifacol.2018.08.275.

[21] W. Yi and L. Özdamar, "A dynamic logistics coordination model for evacuation and support in disaster response activities," European Journal of Operational Research, vol. 179, pp. 1177-1193, 2007. https://doi.org/10.1016/j.ejor.2005.03.077.

[22] A. Kawasaki, N. Ichihara, Y. Ochii, R. A. Acierto, A. Kodaka, and W. W. Zin, "Disaster response and river infrastructure management during the 2015 Myanmar floods: A case in the Bago River Basin," International Journal of Disaster $\begin{array}{lllll}\text { Risk Reduction, } & \text { vol. } 24, \quad \text { pp. } & 151-159, & \end{array}$ https://doi.org/10.1016/j.ijdrr.2017.06.004.

[23] A. B. Milburn, C. Rainwater, O. Boudhoum, and S. Young, "Models for Disaster Relief Shelter Location and Supply Routing," 2013. https://rosap.ntl.bts.gov/view/dot/26064.

[24] C. Mejia-Argueta, J. Gaytán, R. Caballero, J. Molina, and B. Vitoriano, "Multicriteria optimization approach to deploy humanitarian logistic operations integrally during floods," International Transactions in Operational Research, vol. 25, pp. 1053-1079, 2018. https://doi.org/10.1111/itor.12508. 
[25] O. Rodríguez-Espíndola, P. Albores, and C. Brewster, "GIS and optimisation: potential benefits for emergency facility location in humanitarian logistics," Geosciences, vol. 6, p. 18, 2016. https://doi.org/10.3390/geosciences6020018.

[26] A. Muhammad Zainul Abror and S. S. Jumadi, "Analisis Penentuan Lokasi Potensial Shelter Evakuasi dan Desain Evakuasi untuk Bencana Banjir di Kelurahan Sumber, Kecamatan Banjarsari," Universitas Muhammadiyah Surakarta, 2019. https://eprints.ums.ac.id/id/eprint/72105.

[27] P. F. Opit and K. Nakade, "Pre-positioning of Emergency Relief Supplies under Facility Disruptions," daehansaneopgonghakhoe chugyehaksuldaehoe nonmunjip, pp. 3109-3114, 2015.

[28] W. Klibi, S. Ichoua, and A. Martel, "Prepositioning emergency supplies to support disaster relief: a case study using stochastic programming," INFOR: Information Systems and Operational Research, vol. 56, pp. 50-81, 2018. https://doi.org/10.1080/03155986.2017.1335045.

[29] Ç. Renkli and S. Duran, "Pre-Positioning Disaster Response Facilities and Relief Items," Human and Ecological Risk Assessment: An International Journal, vol. 21, pp. 1169-1185, 2015. https://doi.org/10.1080/10807039.2014.957940.

[30] C. G. Rawls and M. A. Turnquist, "Pre-positioning and dynamic delivery planning for short-term response following a natural disaster," Socio-Economic Planning Sciences, vol. 46, pp. 46-54, 2012. https://doi.org/10.1016/j.seps.2011.10.002.

[31] R. Abounacer, M. Rekik, and J. Renaud, "An exact solution approach for multiobjective location-transportation problem for disaster response," Computers \& Operations Research, vol. 41, pp. 83-93, 2014. https://doi.org/10.1016/j.cor.2013.08.001. 